\title{
Activation and signaling of the p38 MAP kinase pathway
}

\author{
Tyler ZARUBIN, Jiahuai HAN* \\ Department of Immunology, The Scripps Research Institute, 10550 N. Torrey Pines Road, La Jolla, CA 92037, USA
}

\begin{abstract}
The family members of the mitogen-activated protein (MAP) kinases mediate a wide variety of cellular behaviors in response to extracellular stimuli. One of the four main sub-groups, the p38 group of MAP kinases, serve as a nexus for signal transduction and play a vital role in numerous biological processes. In this review, we highlight the known characteristics and components of the p38 pathway along with the mechanism and consequences of $\mathrm{p} 38$ activation. We focus on the role of $\mathrm{p} 38$ as a signal transduction mediator and examine the evidence linking p38 to inflammation, cell cycle, cell death, development, cell differentiation, senescence and tumorigenesis in specific cell types. Upstream and downstream components of $\mathrm{p} 38$ are described and questions remaining to be answered are posed. Finally, we propose several directions for future research on $\mathrm{p} 38$.
\end{abstract}

Keywords: p38 MAP kinase, signaling pathway, nexus, inflammation, differentiation, senescence, tumorigenesis.

\section{INTRODUCTION}

Cellular behavior in response to extracellular stimuli is mediated through intracellular signaling pathways such as the mitogen-activated protein (MAP) kinase pathways [1]. MAP kinases are members of discrete signaling cascades and serve as focal points in response to a variety of extracellular stimuli. Four distinct subgroups within the MAP kinase family have been described: (1) extracellular signal-regulated kinases (ERKs), (2) c-jun N-terminal or stress-activated protein kinases (JNK/SAPK), (3) ERK/ big MAP kinase 1 (BMK1), and (4) the p38 group of protein kinases. The focus of this review will be to highlight the characteristics of the p38 kinases, components of this kinase cascade, activation of this pathway, and the biological consequences of its activation.

\section{PROPERTIES OF p38 MAP KINASE MEMBERS}

p38 $\alpha$ (p38) was first isolated as a $38-\mathrm{kDa}$ protein rapidly tyrosine phosphorylated in response to LPS stimulation [2,3]. p38 cDNA was also cloned as a molecule that binds puridinyl imidazole derivatives which are known to inhibit biosynthesis of inflammatory cytokines such as interleukin-1 (IL-1) and tumor-necrosis factor (TNF) in LPS stimulated monocytes [4]. To

\footnotetext{
*Correspondence: Jiahuai HAN

Tel: +858-784-8704; Fax: +858-784-8655;

E-mail: jhan@scripps.edu
}

date, four splice variants of the p38 family have been identified: p38 $\alpha, \mathrm{p} 38 \beta$ [5], p38 $\gamma$ (ERK6, SAPK3) [6,7], and $\mathrm{p} 38 \delta$ (SAPK4) $[8,9]$. Of these, p38 and p38 $\beta$ are ubiquitously expressed while $\mathrm{p} 38 \gamma$ and $\mathrm{p} 38 \delta$ are differentially expressed depending on tissue type. All p38 kinases can be categorised by a Thr-Gly-Tyr (TGY) dual phosphorylation motif [10]. Sequence comparisons have revealed that each p38 isoform shares $\sim 60 \%$ identity within the p38 group but only $40-45 \%$ to the other three MAP kinase family members.

\section{REGULATION OF p38 SIGNALING PATHWAY Extracellular stimuli}

p38 activation has been observed in response to a variety of extracellular stimuli in different organisms and homologues of $\mathrm{p} 38$ have been identified and cloned in yeast (Hog1 \& Spc/Sty1), worm (pmk-2), fly (p38a,b,c), and frog (p38) [1,11-13]. In yeast, the Hog1 \& Spc/Sty1 pathways have been implicated in osmoregulation, responses to extracellular stress stimuli, and cell-cycle events [12-14]. Mammalian p38s show similar roles and activation has been shown to occur in response to extracellular stimuli such as UV light, heat, osmotic shock, inflammatory cytokines (TNF- $\alpha$ \& IL-1), and growth factors (CSF-1) $[1,3,15-$ 21]. This plethora of activators conveys the complexity of the p38 pathway and this matter is further complicated by the observation that activation of $\mathrm{p} 38 \alpha$ is not only dependent on stimulus, but on cell type as well. For example, 
insulin can stimulate p38 in 3T3-L1 adipocytes [22], but downregulates $\mathrm{p} 38$ activity in chick forebrain neuron cells [23]. Although the other three p38 group members have been cloned for quite some time now, little is known regarding their activation. Despite research that has shown that all four $\mathrm{p} 38$ group members display similar activation profiles $[5,8,24,25]$, differences have been observed in the kinetics and level of activation of these isoforms. Furthermore, the activation of p38 isoforms can be specifically controlled through different regulators and coactivated by various combinations of upstream regulators $[24,26]$.

\section{Upstream kinases that activate $\mathbf{p 3 8}$}

Like all MAP kinases, p38 kinases are activated by dual kinases termed the MAP kinase kinases (MKKs). However, despite conserved dual phosphorylation sites among p38 isoforms, selective activation by distinct MKKs has been observed. There are two main MAPKKs that are known to activate $\mathrm{p} 38, \mathrm{MKK} 3$ and MKK6. It is proposed that upstream kinases can differentially regulate p38 isoforms as evidenced by the inability of MKK3 to effectively activate p38ß while MKK6 is a potent activator despite $80 \%$ homology between these two MKKs [27]. Also, it has been shown that MKK4, an upstream kinase of JNK, can aid in the activation of $\mathrm{p} 38 \alpha$ and $\mathrm{p} 38 \delta$ in specific cell types[8]. This data suggests then, that activation of p38 isoforms can be specifically controlled through different regulators and coactivated by various combinations of upstream regulators. Furthermore, substrate selectivity may be a reason why each MKK has a distinct function. In addition to the activation by upstream kinases, there is a MAPKKindependent mechanism of $\mathrm{p} 38$ MAPK activation involving TAB1 (transforming growth factor- $\beta$-activated protein kinase 1 (TAK1)-binding protein) [28]. The activation of p38 in this pathway is achieved by the autophosphorylation of p38 $\alpha$ after interaction with TAB1. Although there is an indication that TAB1-dependent $\mathrm{p} 38$ phosphorylation occurs in LPS, TNF, and CpG treated B cell lines, a study using MKK3/6 knockout MEF cells showed that TNFinduced p38 activation is solely dependent on MKKs [29]. While the biological contexts of MKK-independent p38 activation still need further investigation, there is a couple of recent publications that support the role TAB-dependent p38 activation under physiological conditions [30-32]. This suggests that the activation mechanisms of $\mathrm{p} 38$ may vary in different cells under various physiological or pathological conditions.

\section{Further upstream activators}

The activation of $\mathrm{p} 38$ in response to the wide range of extracellular stimuli can be seen in part by the diverse range of MKK kinases (MAP3K) that participate in p38 activation. These include TAK1 [33], ASK1/MAPKKK5 [34], DLK/MUK/ZPK [35,36], and MEKK4 [35,37,38]. Overexpression of these MAP3Ks leads to activation of both p38 and JNK pathways which is possibly one reason why these two pathways are often co-activated. Specific activation of p38 or JNK has been observed, though, implying explicit activation of p38 at this level [39].

Also contributing to $\mathrm{p} 38$ activation upstream of MAPK kinases are low molecular weight GTP-binding proteins in the Rho family such as Rac1 and Cdc42 [40,41]. Rac1 can bind to MEKK1 or MLK1 while Cdc42 can only bind to MLK1 and both result in activation of $\mathrm{p} 38$ via MAP3Ks [35,42]. p21-activated kinases (PAKs) are yet another group of p38 activators. In vitro data has shown that PAK1, PAK2, and PAK3 are activated by binding to Cdc 42 and Rac $[41,43,44]$.

\section{Downregulation of the $\mathrm{p38}$ signaling pathway}

Under physiological conditions, MAP kinase activation is often transient despite the unchanging level of MAP kinases throughout the course of stimulation.

Dephosphorylation, then, would seem to play a major role in the downregulation of MAP kinase activity. Many dual-specificity phosphatases have been identified that act upon various members of the MAP kinase pathway and are grouped as the MAP kinase phosphatase (MKP) family [45]. Several members can efficiently dephosphorylate $\mathrm{p} 38 \alpha$ and $\mathrm{p} 38 \beta[46,47]$; however, $\mathrm{p} 38 \gamma$ and $\mathrm{p} 38 \delta$ are resistant to all known MKP family members. In addition, other types of phosphatases such as serine/ threonine protein phosphotase type 2C (PP2C) has been shown to have a role in downregulating the MAP kinase HOG1 pathway as well as negatively regulating human MKK6 and MKK4 levels in vitro and in vivo [48-51]. Taken together, these results suggest a mechanism by which p38 isoforms are differentially regulated depending on phosphatase levels and specificity.

\section{DOWNSTREAM SUBSTRATES OF P38 GROUP MAP KINASES}

\section{Protein kinase substrates of p38}

The first $\mathrm{p} 38 \alpha$ substrate identified was the MAP kinase-activated protein kinase 2 (MAPKAPK2 or MK2) [1, $15,52]$. This substrate, along with its closely related family member MK3 (3pk), were both shown to activate various substrates including small heat shock protein 27 (HSP27) [53], lymphocyte-specific protein 1 (LSP1) [54], cAMP response element-binding protein (CREB) [55], transcription factor ATF1 [55], SRF [56], and tyrosine hydroxylase [57]. More recently, MK2 has been found to phosphorylate tristetraprolin (TTP), a protein that is known 
to destabilize mRNA hinting at a role for p38 in mRNA stability [58]. MNK1 is another kinase substrate of p38 whose function is thought to reside in translational initiation due to the observation that MNK1 and MNK2 can phosphorylate eukaryotic initiation factor-4e (eIF-4E) $[59,60]$. p38 regulated/activated kinase (PRAK) is a p38 $\alpha$ and/or p38 $\beta$ activated kinase that shares $20-30 \%$ sequence identity to MK2 and is thought to regulate heat shock protein 27 (HSP27) [61]. Mitogen- and stress-activated protein kinase-1 (MSK1) can be directly activated by $\mathrm{p} 38$ and ERK, and may mediate activation of CREB [62-64]. p38 is also thought to regulate $\mathrm{S}$ phase activation of histone $2 \mathrm{~B}$ (H2B) promoter through OCA-S, a component of p38 [65].

\section{Transcription factors activated by $\mathrm{p38}$}

Another group of substrates that are activated by p38 comprise transcription factors. Many transcription factors encompassing a broad range of action have been shown to be phosphorylated and subsequently activated by $\mathrm{p} 38$. Examples include activating transcription factor $1,2 \& 6$ (ATF-1/2/6), SRF accessory protein (Sap1), CHOP (growth arrest and DNA damage inducible gene 153, or GADD153), p53, C/EBP $\beta$, myocyte enhance factor $2 \mathrm{C}$ (MEF2C), MEF2A, MITF1, DDIT3, ELK1, NFAT, and high mobility group-box protein 1 (HBP1) [17,55,66-76] . An important cis-element, AP-1 appears to be influenced by 338 through several different mechanisms. ATF-2 is known to form heterodimers with Jun family transcription factors thereby directly associating with the AP1 binding site [71]. Another possible mechanism comes from the observation that a component of AP-1 is c-fos. c-fos is known to be SRE dependent and SRE is able to bind Ternary Complex Factor (TCF). Ternary Complex Factor is comprised of Sap-1a, a protein that is phosphorylated by $\mathrm{p} 38$. Thus, $\mathrm{p} 38$ indirectly regulates AP-1 activity. ERK and JNK can also mediate another component of the TCF called Elk-1 [77]. It is thought then that there is coordinated participation of the three MAP kinases in regulation of c-fos expression. Recently, the HBP1 transcription factor has been identified as a substrate for $\mathrm{p} 38$. HBP1 has been linked to G1 cell cycle arrest and inhibition of p38 has been shown to decrease HBP1 protein levels [73].

\section{Other types of substrates for p38}

cPLA2, Na+/H+ exchanger isoform-1 (NHE-1), tau and keratin 8 have also been reported as substrates for $\mathrm{p} 38 \alpha$ [78-81]. Furthermore, stathmin is another substrate for p38 $\alpha$ [27]. Taken together, all the data suggest that the p38 pathway has a wide variety of functions.

\section{GENES REGULATED BY THE p38 PATHWAY}

Through the use of inactive and constitutively active mutants of MKK3 and 6 as well as the p38 inhibitor SB203580, numerous genes regulated by the p38 MAP kinase pathway have been identified. These genes encompass a wide range of families including cytokines, transcription factors and cell surface receptors. We have mentioned earlier that about half of p38 substrates identified so far are transcription factors. So, it is obvious that p38 has a role in regulating gene expression at the transcriptional level. Post-transcriptional regulation of inflammatory gene expression has also been linked with the $\mathrm{p} 38$ pathway $[82$, 83]. $\mathrm{TNF} \alpha$ and IL-1 $\beta$ steady-state mRNA levels exhibited little or no change when protein synthesis was blocked with p38 inhibitors suggesting a role for p38 in the translation of these transcripts. MK2 knockout mice resulted in impairment of TNF $\alpha$ protein synthesis while TNF $\alpha$ mRNA steady-state levels remained unchanged $[84,85]$. Furthermore, a genomic deletion of a conserved AU rich element (ARE) in the TNF $\alpha$ 3' untranslated region (UTR) of mice caused overproduction of TNF $\alpha$ and a loss of sensitivity to p38 inhibitors. Taken together, this suggests p38 may act through MK2 to release TNF $\alpha$ mRNA from translational arrest imposed by the ARE [86].

\section{BIOLOGICAL CONSEQUENCES OF P38 ACTI- VATION}

\section{p38 and inflammation}

A strong link has been established between the p38 pathway and inflammation. Rheumatoid arthritis, Alzheimer's disease and inflammatory bowel disease are all postulated to be regulated in part by the p38 pathway [87-89]. The activation of the $\mathrm{p} 38$ pathway plays essential roles in the production of proinflammatory cytokines (IL- $1 \beta$, TNF- $\alpha$ and IL-6) [90]; induction of enzymes such as COX-2 which controls connective tissue remodeling in pathological conditions [91]; expression of intracellular enzymes such as iNOS, a regulator of oxidation [92,93]; induction of VCAM-1 and other adherent proteins along with other inflammatory related molecules [18]. In addition, a regulatory role for $\mathrm{p} 38$ in the proliferation and differentiation of immune system cells such as GM-CSF, EPO, CSF and CD-40 has been established [16,94].

\section{p38 and apoptosis}

Abundant evidence for p38 involvement in apoptosis exists to date and is based on concomitant activation of p38 and apoptosis induced by a variety of agents such as NGF withdrawal and Fas ligation [95-97]. Cysteine proteases (caspases) are central to the apoptotic pathway and are expressed as inactive zymogens $[98,99]$. Caspase inhibitors then can block p38 activation through Fas crosslinking, suggesting p38 functions downstream of caspase activation $[97,100]$. However, overexpression of domi- 
nant active MKK6b can also induce caspase activity and cell death thus implying that p38 may function both upstream and downstream of caspases in apoptosis [101, 102]. It must be mentioned that the role of $\mathrm{p} 38$ in apoptosis is cell type and stimulus dependent. While p38 signaling has been shown to promote cell death in some cell lines, in different cell lines p38 has been shown to enhance survival, cell growth, and differentiation.

\section{p38 in the cell cycle}

The participation of $\mathrm{p} 38 \alpha$ in cell growth has been observed in both yeast and mammals [103]. Overexpression of $\mathrm{p} 38 \alpha$ in yeast led to significant slowing of proliferation while treatment in mammalian cells with $\mathrm{p} 38 \alpha / \beta$ inhibitor SB203580 slowed proliferation as well. p38 has been implicated in G1 and G2/M phases of the cell cycle in several reports $[73,104,105]$. G1 arrest of NIH3T3 cells caused by microinjection of Cdc42 was found to be $\mathrm{p} 38 \alpha-$ dependent [105]. Also, as mentioned earlier, a link between p38 and G1 cell cycle control has been proposed through the regulation of p38 substrates HBP1 and p21 [73]. HBP1 is thought to have a role in regulating G1 cell cycle progression through repression of cell cycle regulatory genes, similar in function to retinoblast protein (RB) while the p21 CDK inhibitor is established as a crucial factor in preventing G1 progression through blockage of CDK activity. p38 involvement in $\mathrm{G} 2 / \mathrm{M}$ phase is seen through several examples as well. p38 $\alpha$ is activated in mammalian cells upon $\mathrm{M}$ phase arrest by disruption of the spindle with nocodazole [104]. Furthermore, it has been shown that p38 $\alpha$ and p38 $\gamma$ are required for UV-induced G2 cell cycle arrest [106].

\section{p38 and cardiomyocyte hypertrophy}

Since p38 is a stress-activated kinase, activation and function in cardiomyocyte hypertrophy has been studied. During progression of hypertrophy, both p38 $\alpha$ and p38 $\beta$ levels were increased and constitutively active MKK3 and MKK6-elicited hypertrophic responses enhanced by sarcomeric organization and elevated atrial natriuretic factor expression. Also, reduced signaling of p38 in the heart promotes myocyte differentiation via a mechanism involving calcineurin-NFAT signaling [107].

\section{p38 and development}

Despite the non-viability of p38 knockout mice, evidence exists regarding the differential role of p38 in development. p38 has been linked to placental angiogenesis but not cardiovascular development in several studies. Furthermore, p38 has also been linked to erythropoietin expression suggesting a role in erythropoiesis [108111]. PRAK has recently been implicated in cell develop- ment in murine implantation. PRAK mRNA, as well as p38 isoforms, were found to be expressed throughout blastocyst development [112].

\section{p38 and cell differentiation}

$\mathrm{p} 38 \alpha$ and $\mathrm{p} 38 \beta$ have been implicated in cell differentiation for certain cell types. Differentiation of 3T3-L1 cells into adipocytes and PC12 cells into neurons requires $\mathrm{p} 38 \alpha$ and/or $\beta[113,114]$. p38 was also found to be required and sufficient for SKT6 differentiation into haemoglobinised cells [115]. More recently, a cross-talk model has been proposed between the p38 pathway and phosphatidylinositol 3-kinase (PI3 kinase)/Akt in the orchestration of myoblast differentiation [116].

\section{p38 in senescence and tumor suppression}

p38 now seems to have a role in tumorigenesis and sensescence. There have been reports that activation of MKK6 and MKK3 led to a senescent phenotype dependent upon p38 MAPK activity. Also, p38 MAPK activity was shown responsible for senescence in response to telomere shortening, $\mathrm{H}_{2} \mathrm{O}_{2}$ exposure, and chronic RAS oncogene signaling [117-119]. A common feature of tumor cells is a loss of senescence and p38 may be linked to tumorigenesis in certain cells. It has been reported that p38 activation may be reduced in tumors and that loss of components of the p38 pathway such as MKK3 and MKK6 resulted in increased proliferation and likelihood of tumorigenic conversion regardless of the cell line or the tumor induction agent used in these studies [29].

\section{DISCUSSSION}

Although all research done on the p38 pathway cannot be reviewed here, certain conclusions can still be made regarding the operation of $\mathrm{p} 38$ as a signal transduction mediator. The p38 family $(\alpha, \beta, \gamma, \delta)$ is activated by both stress and mitogenic stimuli in a cell dependent manner and certain isoforms can either directly or indirectly target proteins to control pre/post transcription. p38 MAPKs also have the ability to activate other kinases and consequently regulate numerous cellular responses. Because p38 signaling has been implicated in cellular responses including inflammation, cell cycle, cell death, development, cell differentiation, senescence, and tumorigenesis, emphasis must be placed on $\mathrm{p} 38$ function with respect to specific cell types.

Despite all that is known regarding p38 structure and function, many questions still remain. However, new evidence linking p38 to senescence, tumorigenesis and post transcriptional regulation has shed some more light on p38 function and regulation. The activity of $\mathrm{p} 38 \alpha$ has been proven instrumental in cytokine gene expression. However, 
the role of $\mathrm{p} 38$ becomes nebulous when the influence of p38 transcription factors on cytokine expression is considered. Transcription factors of $\mathrm{p} 38$ predicted to influence TNF transcription had little or no effect but new insights on post-transcriptional gene regulation by $\mathrm{p} 38$ have begun to elucidate possible mechanisms by which p38 regulates TNF gene expression.

Regulation of the p38 pathway is not an isolated cascade and many different upstream signals can lead to $\mathrm{p} 38$ activation. These signals may be $\mathrm{p} 38$ specific (MKK3/6), general MAPKKs (MKK4), or MAPKK independent signals (TAB1). Downstream signaling pathways of p38 are quite divergent and each component may interact with other cellular components, both upstream and downstream, to coordinate cellular processes such as feedback mechanisms. Furthermore, in vivo p38 is not an isolated event and exists in the presence of other MAP kinases and a plethora of other signaling pathways. The subcellular location of p38 activation may also play a critical role determining the resulting effect and may add yet another order of complexity to the investigation of $\mathrm{p} 38$ function. Future work would benefit from attention to the interaction between different pathways, the balance/regulation among signaling events, and subcellular location of p38 activation.

\section{REFERENCES}

1 Rouse J, Cohen P, Trigon S, et al. A novel kinase cascade triggered by stress and heat shock that stimulates MAPKAP kinase-2 and phosphorylation of the small heat shock proteins. Cell 1994; 78:1027-37.

2 Han J, Lee JD, Tobias PS, Ulevitch RJ. Endotoxin induces rapid protein tyrosine phosphorylation in 70Z/3 cells expressing CD14. J Biol Chem 1993; 268:25009-14.

3 Han J, Lee JD, Bibbs L, Ulevitch RJ. A MAP kinase targeted by endotoxin and hyperosmolarity in mammalian cells. Science 1994; 265:808-11.

4 Lee JC, Laydon JT, McDonnell PC, et al. A protein kinase involved in the regulation of inflammatory cytokine biosynthesis. Nature 1994; 372:739-46.

5 Jiang Y, Chen C, Li Z, et al. Characterization of the structure and function of a new mitogen-activated protein kinase (p38b). J Biol Chem 1996; 271:17920-6.

6 Lechner C, Zahalka MA, Giot JF, Moler NPH, Ullrich A. ERK6, a mitogen-activated protein kinase involved in $\mathrm{C} 2 \mathrm{C} 12$ myoblast differentiation. Proc Natl Acad Sci USA 1996; 93:4355-9.

7 Li Z, Jiang Y, Ulevitch RJ, Han J. The primary structure of p38gamma: A new member of 338 group of MAP kinase. Biochem Biophys Res Comm 1996; 228:334-40.

8 Jiang Y, Gram H, Zhao M, et al. Characterization of the structure and function of the fourth member of $\mathrm{p} 38$ group mitogenactivated protein kinases, p38delta. J Biol Chem 1997; 272: 30122-8.

9 Kumar S, McDonnell PC, Gum RJ, et al. Novel homologues of $\mathrm{CSBP} / \mathrm{p} 38$ MAP kinase: activation, substrate specificity and sensitivity to inhibition by pyridinyl imidazoles. Biochem
Biophys Res Commun 1997; 235:533-8.

10 Hanks SK, Hunter T. The eukaryotic protein kinase superfamily: kinase (catalytic) domain structure and classification. FASEB J 1999; 9:576-96.

11 Han SJ, Choi KY, Brey PT, Lee WJ. Molecular cloning and characterization of a Drosophila p38 mitogen-activated protein kinase. J Biol Chem 1998; 273:369-74.

12 Brewster JL, de Valoir T, Dyer ND, Winter E, Gustin MC. An osmosensing signal transduction pathway in yeast. Science 1993; 259:1760-3.

13 Shiozaki K, Russell P. Cell-cycle control linked to extracellular environment by MAP kinase pathway in fission yeast. Nature 1995; 378:739-43.

14 Shiozaki K, Russell P. Conjugation, meiosis, and the osmotic stress response are regulated by Spc1 kinase through Atf1 transcription factor in fission yeast. Genes Dev 1996; 10:2276-88.

15 Freshney NW, Rawlinson L, Guesdon F, et al. Interleukin-1 activates a novel protein kinase cascade that results in the phosphorylation of Hsp27. Cell 1994; 78:1039-49.

16 Lee JC, Laydon JT, McDonnell PC, et al. Identification and characterization of a novel protein kinase involved in the regulation of inflammatory cytokine biosynthesis. Nature 1994; 372: 739-46.

17 Raingeaud J, Gupta S, Rogers JS, et al. Pro-inflammatory cytokines and environmental stress cause p38 mitogen-activated protein kinase activation by dual phosphorylation on tyrosine and threonine. J Biol Chem 1995; 270:7420-6.

18 Pietersma A, Tilly BC, Gaestel M, et al. p38 mitogen activated protein kinase regulates endothelial VCAM-1 expression at the post-transcriptional level. Biochem Biophys Res Comm 1997; 230:44-8.

19 Shalom-Barak T, Quach J, Lotz M. Interleukin-17-induced gene expression in articular chondrocytes is associated with activation of mitogen-activated protein kinases and NF-kappaB. J Biol Chem 1998; 273:27467-73.

20 Shapiro L, Puren AJ, Barton HA, et al. Interleukin 18 stimulates HIV type 1 in monocytic cells. Proc Natl Acad Sci U S A 1998; 95:12550-5.

21 Foltz IN, Lee JC, Young PR, Schrader JW. Hemopoietic growth factors with the exception of interleukin- 4 activate the p38 mitogen-activated protein kinase pathway. J Biol Chem 1997; 272: 3296-3301.

22 Sweeney G, Somwar R, Ramlal T, et al. An inhibitor of p38 mitogen-activated protein kinase prevents insulin-stimulated glucose transport but not glucose transporter translocation in 3T3L1 adipocytes and L6 myotubes. J Biol Chem 1999; 274:100718.

23 Heidenreich KA, Kummer JL. Inhibition of p38 mitogen-activated protein kinase by insulin in cultured fetal neurons. J Biol Chem 1996; 271:9891-4.

$24 \mathrm{Hu}$ MC, Wang YP, Mikhail A, Qiu WR, Tan TH. Murine p38delta mitogen-activated protein kinase, a developmentally regulated protein kinase that is activated by stress and proinflammatory cytokines. J Biol Chem 1999; 274:7095-102.

25 Cuenda A, Cohen P, Buee-Scherrer V, Goedert M. Activation of stress-activated protein kinase-3 (SAPK3) by cytokines and cellular stresses is mediated via SAPKK3 (MKK6); comparison of the specificities of SAPK3 and SAPK2 (RK/p38). EMBO J 1997; 16:295-305. 
26 Enslen H, Raingeaud J, Davis RJ. Selective activation of p38 mitogen-activated protein (MAP) kinase isoforms by the MAP kinase kinases MKK3 and MKK6. J Biol Chem 1998; 273: 1741-8.

27 Parker CG, Hunt J, Diener K, et al. Identification of stathmin as a novel substrate for $\mathrm{p} 38$ delta. Biochem Biophys Res Commun 1998; 249:791-6.

28 Ge B, Gram H, Di Padova F, et al. MAPKK-independent activation of p38alpha mediated by TAB 1 -dependent autophosphorylation of p38alpha. Science 2002; 295:1291-4..

29 Brancho D, Tanaka N, Jaeschke A, et al. Mechanism of p38 MAP kinase activation in vivo. Genes Dev 2003; 17:1969-78.

30 Ohkusu-Tsukada K, Tominaga N, Udono H, Yui K. Regulation of the maintenance of peripheral T-cell anergy by TAB1-mediated p38 alpha activation. Mol Cell Biol 2004; 24:6957-66.

31 Matsuyama W, Faure M, Yoshimura T. Activation of discoidin domain receptor 1 facilitates the maturation of human monocyte-derived dendritic cells through the TNF receptor associated factor 6/TGF-beta-activated protein kinase 1 binding protein 1 beta/p38 alpha mitogen-activated protein kinase signaling cascade. J Immunol 2003; 171:3520-32.

32 Tanno M, Bassi R, Gorog DA, et al. Diverse mechanisms of myocardial p38 mitogen-activated protein kinase activation: evidence for MKK-independent activation by a TAB1-associated mechanism contributing to injury during myocardial ischemia. Circ Res 2003; 93:254-61.

33 Moriguchi T, Kuroyanagi N, Yamaguchi K, et al. A novel kinase cascade mediated by mitogen-activated protein kinase kinase 6 and MKK3. J Biol Chem 1996; 271:13675-9.

34 Ichijo H, Nishida E, Irie K, et al. Induction of apoptosis by ASK1, a mammalian MAPKKK that activates SAPK/JNK and p38 signaling pathways. Science 1997; 275:90-4.

35 Hirai S, Katoh M, Terada M, et al. MST/MLK2, a member of the mixed lineage kinase family, directly phosphorylates and activates SEK1, an activator of c-Jun N- terminal kinase/stressactivated protein kinase. J Biol Chem 1997; 272:15167-73.

36 Ubeda M, Wang XZ, Zinszner H, et al. Stress-induced binding of the transcriptional factor CHOP to a novel DNA control element. Mol Cell Biol 1996; 16:1479-89.

37 Cuenda A, Dorow DS. Differential activation of stress-activated protein kinase kinases SKK4/MKK7 and SKK1/MKK4 by the mixed-lineage kinase-2 and mitogen-activated protein kinase kinase (MKK) kinase-1. Biochem J 1998; 333:11-5.

38 Takekawa M, Posas, F, Saito H. A human homolog of the yeast Ssk2/Ssk22 MAP kinase kinase kinases, MTK1, mediates stressinduced activation of the p38 and JNK pathways. EMBO J 1997; 16:4973-82.

39 Ogura M, Kitamura M. Oxidant stress incites spreading of macrophages via extracellular signal-regulated kinases and p38 mitogen-activated protein kinase. J Immunol 1998; 161:3569-74.

40 Zhang S, Han J, Sells MA, et al. Rho family GTPases regulate p38 MAP kinase through the downstream mediator Pak1. J Biol Chem 1995; 270:23934-6.

41 Bagrodia S, Derijard B, Davis RJ, Cerione RA. Cdc42 and PAKmediated signaling leads to Jun kinase and p38 mitogen-activated protein kinase activation. J. Biol. Chem 1995; 270:27995-8.

42 Tibbles LA, Ing YL, Kiefer F, et al. MLK-3 activates the SAPK/ JNK and p38/RK pathways via SEK1 and MKK3/6. EMBO J 1996; 15:7026-35.
43 Martin GA, Bollag G, McCormick, F, Abo A. A novel serine kinase activated by rac1/CDC42Hs-dependent autophosphorylation is related to PAK65 and STE20. EMBO J 1995; 14: 1970-8.

44 Manser E, Leung T, Salihuddin H., Zhao Z, Lim L. A brain serine/threonine protein kinase activated by $\mathrm{Cdc} 42$ and Rac1. Nature 1994; 367:40-6.

45 Sun H, Charles CH, Lau LF, Tonks NK. MKP-1 (3CH134), an immediate early gene product, is a dual specificity phosphatase that dephosphorylates MAP kinase in vivo. Cell 1993; 75:48793.

46 Camps M, Nichols A, Gillieron C, et al. Catalytic activation of the phosphatase MKP-3 by ERK2 mitogen-activated protein kinase. Science 1998; 280:1262-5.

47 Muda M, Theodosiou A, Rodrigues N, et al. The dual specificity phosphatases M3/6 and MKP-3 are highly selective for inactivation of distinct mitogen-activated protein kinases. J Biol Chem 1996; 271:27205-8.

48 Maeda T, Wurgler-Murphy SM, Saito H. A two-component system that regulates an osmosensing MAP kinase cascade in yeast. Nature 1994; 369:242-5.

49 Posas F, Wurgler-Murphy SM, Maeda T, et al. Yeast HOG1 MAP kinase cascade is regulated by a multistep phosphorelay mechanism in the SLN1-YPD1-SSK1 "two-component" osmosensor. Cell 1996; 86:865-75.

50 Wurgler-Murphy SM, Maeda T, Witten EA, Saito H. Regulation of the Saccharomyces cerevisiae HOG1 mitogen- activated protein kinase by the PTP2 and PTP3 protein tyrosine phosphatases. Mol Cell Biol 1997; 17:1289-97.

51 Takekawa M, Maeda T, Saito H. Protein phosphatase 2Calpha inhibits the human stress-responsive p38 and JNK MAPK pathways. EMBO J 1998; 17:4744-52.

52 McLaughlin MM, Kumar S, McDonnell PC, et al. Identification of mitogen-activated protein (MAP) kinase-activated protein kinase-3, a novel substrate of CSBP p38 MAP kinase. J Biol Chem 1996; 271:8488-92.

53 Stokoe D, Engel K, Campbell DG, Cohen P, Gaestel M. Identification of MAPKAP kinase 2 as a major enzyme responsible for the phosphorylation of the small mammalian heat shock proteins. FEBS 1992; 313:307-13.

54 Huang CK, Zhan L, Ai Y, Jongstra J. LSP1 is the major substrate for mitogen-activated protein kinase- activated protein kinase 2 in human neutrophils. J Biol Chem 1997; 272:17-9.

55 Tan Y, Rouse J, Zhang A, et al. FGF and stress regulate CREB, ATF-1 via a pathway involving $\mathrm{p} 38$ MAP kinase and MAPKAP kinase-2. EMBO J 1996; 15:4629-42.

56 Heidenreich O, Neininger A, Schratt G, et al. MAPKAP kinase 2 phosphorylates serum response factor in vitro and in vivo. $\mathrm{J}$ Biol Chem 1999; 274:14434-43.

57 Thomas G, Haavik J, Cohen P. Participation of a stress-activated protein kinase cascade in the activation of tyrosine hydroxylase in chromaffin cells. Eur J Biochem 1997; 247:1180-9.

58 Mahtani KR, Brook M, Dean JL, et al. Mitogen-activated protein kinase p38 controls the expression and posttranslational modification of tristetraprolin, a regulator of tumor necrosis factor alpha mRNA stability. Mol Cell Biol 2001; 21:6461-9.

59 Waskiewicz AJ, Flynn A, Proud CG, Cooper JA. Mitogen-activated protein kinases activate the serine/threonine kinases Mnk1 and Mnk2. EMBO J 1997; 16:1909-20. 
60 Fukunaga R, Hunter T. MNK1, a new MAP kinase-activated protein kinase, solated by a novel expression screening method for identifying protein kinase substrates. EMBO J 1997; 16: 1921-33.

61 New L, Jiang Y, Zhao M, et al. PRAK, a novel protein kinase regulated by the p38 MAP kinase. EMBO J 1998; 17:3372-84.

62 Deak M, Clifton AD, Lucocq LM, Alessi DR. Mitogen- and stress-activated protein kinase-1 (MSK1) is directly activated by MAPK and SAPK2/p38, and may mediate activation of CREB. EMBO J 1998; 17:4426-41.

63 Pierrat B, Correia JS, Mary JL, Tomas-Zuber M, Lesslauer W. RSK-B, a novel ribosomal S6 kinase family member, is a CREB kinase under dominant control of p38alpha mitogen-activated protein kinase (p38alphaMAPK). J Biol Chem 1998; 273:2966171.

64 New L, Zhao M, Li Y, et al. Cloning and characterization of RLPK, a novel RSK-related protein kinase. J Biol Chem 1999; 274:1026-32.

65 Zheng L, Roeder RG, Luo Y. S phase activation of the histone H2B promoter by OCA-S, a coactivator complex that contains GAPDH as a key component. Cell 2003; 114:255-66.

66 Hazzalin CA, Cano E, Cuenda A, et al. p38/RK is essential for stress-induced nuclear responses: JNK/SAPKs and c-Jun/ATF2 phosphorylation are insufficient. Curr Biol 1996; 6:1028-31.

67 Whitmarsh AJ, Yang SH, Su MS, Sharrocks AD, Davis RJ. Role of $\mathrm{p} 38$ and JNK mitogen-activated protein kinases in the activation of ternary complex factors. Mol Cell Biol 1997; 17:236071.

68 Janknecht R, Hunter T. Convergence of MAP kinase pathways on the ternary complex factor Sap-1a. EMBO J 1997; 16:1620-7.

69 Wang XZ, Ron D. Stress-induced phosphorylation and activation of the transcription factor CHOP (GADD153) by p38 MAP Kinase. Science 1996; 272:1347-9.

70 Han J, Jiang Y, Li Z, Kravchenko VV, Ulevitch RT. Activation of the $\mathrm{t}$ transcription factor MEF2C by the MAP kinase $\mathrm{p} 38$ in inflammation. Nature 1997; 386:296-9.

71 Zhao M, New L, Kravchenko VV, et al. Regulation of the MEF2 family of transcription factors by p38. Mol Cell Biol 1999; 19: 21-30.

72 Huang C, Ma WY, Maxiner A, Sun Y, Dong Z.p38 kinase mediates UV-induced phosphorylation of $\mathrm{p} 53$ protein at serine 389 . J Biol Chem 1999; 274:12229-35.

73 Yee AS, Paulson EK, McDevitt MA, et al. The HBP1 transcriptional repressor and the p38 MAP kinase: unlikely partners in G1 regulation and tumor suppression. Gene 2004; 336:113.

74 Galibert MD, Carreira S, Goding CR. The Usf-1 transcription factor is a novel target for the stress- responsive p38 kinase and mediates UV-induced Tyrosinase expression. EMBO J 2001; 20:5022-31.

75 Pereira RC, Delany AM, Canalis E. CCAAT/enhancer binding protein homologous protein (DDIT3) induces osteoblastic cell differentiation. Endocrinology 2004; 145:1952-60.

76 Gomez del Arco P, Martinez-Martinez S, Maldonado JL, OrtegaPerez I, Redondo JM. A role for the p38 MAP kinase pathway in the nuclear shuttling of NFATp. J Biol Chem 2000; 275: 13872-8.

77 Kramer RM, Roberts EF, Um SL, et al. p38 mitogen-activated protein kinase phosphorylates cytosolic phospholipase A2
(cPLA2) in thrombin-stimulated platelets. Evidence that proline-directed phosphorylation is not required for mobilization of arachidonic acid by cPLA2. J Biol Chem 1996; 271:27723-9.

78 Kusuhara M, Takahashi E, Peterson TE, et al. p38 Kinase is a negative regulator of angiotensin II signal $t$ transduction in vascular smooth muscle cells: effects on $\mathrm{Na}+\mathrm{H}+$ exchange and ERK1/2. Circ Res 1998; 83:824-31.

79 Reynolds CH., Nebreda AR, Gibb GM., Utton MA, Anderton $\mathrm{BH}$. Reactivating kinase/p38 phosphorylates tau protein in vitro. J Neurochem 1997; 69:191-8.

80 Feng L, Zhou X, Liao J, Omary MB. Pervanadate-mediated tyrosine phosphorylation of keratins 8 and 19 via a p38 mitogenactivated protein kinase-dependent pathway. J Cell Sci 1999; 112:2081-90

81 Young P, McDonnell P, Dunnington D, et al. Pyridinyl imidazoles inhibit IL-1 and TNF production at the protein level. Agents Actions 1993; 39:C67-9.

82 Prichett W, Hand A, Sheilds J, Dunnington D. Mechanism of action of bicyclic imidazoles defines a translational regulatory pathway for tumor necrosis factor alpha. J Inflamm 1995; 45: 97-105.

83 Kotlyarov A, Neininger A, Schubert C, et al. MAPKAP kinase 2 is essential for LPS-induced TNF-alpha biosynthesis. Nat Cell Biol 1999; 1:94-7.

84 Kontoyiannis D, Kotlyarov A, Carballo E, et al. Interleukin-10 targets p38 MAPK to modulate ARE-dependent TNF mRNA translation and limit intestinal pathology. EMBO J 2001; 20: 3760-70.

85 Kontoyiannis D, Pasparakis M, Pizarro TT, Cominelli F, Kollias G. Impaired on/off regulation of TNF biosynthesis in mice lacking TNF AU-rich elements: implications for joint and gut-associated immunopathologies. Immunity 1999; 10:387-98.

86 Sweeney SE, Firestein GS. Signal transduction in rheumatoid arthritis. Curr Opin Rheumatol 2004; 16:231-7.

87 Johnson GV, Bailey CD. The p38 MAP kinase signaling pathway in Alzheimer's disease. Exp Neurol 2003; 183:263-8.

88 Hollenbach E, Neumann M, Vieth M, et al. Inhibition of p38 MAP kinase- and RICK/NF-kappaB-signaling suppresses inflammatory bowel disease. FASEB J 2004; 13:1550-2.

89 Perregaux DG, Dean D, Cronan M, Connelly P, Gabel C. A. Inhibition of interleukin-1 beta production by SKF86002: evidence of two sites of in vitro activity and of a time and system dependence. Mol Pharmacol 1995; 48:433-42.

90 Guan Z, Buckman SY, Pentland AP, Templeton DJ, Morrison AR. Induction of cyclooxygenase- 2 by the activated MEKK1 $\longrightarrow$ SEK1/MKK4 $\rightarrow$ p38 mitogen-activated protein kinase pathway. J Biol Chem 1998; 273:12901-8.

91 Badger AM, Cook MN, Lark MW, et al. SB 203580 inhibits p38 mitogen-activated protein kinase, nitric oxide production, and inducible nitric oxide synthase in bovine cartilage-derived chondrocytes. J Immunol 1998; 161:467-73.

92 Da Silva J, Pierrat B, Mary JL, Lesslauer W. Blockade of p38 mitogen-activated protein kinase pathway inhibits inducible nitric-oxide synthase expression in mouse astrocytes. J Biol Chem 1997; 272:28373-80.

93 Craxton A, Shu G, Graves JD, et al. p38 MAPK is required for CD40-induced gene expression and proliferation in $\mathrm{B}$ lymphocytes. J Immunol 1998; 161:3225-36.

94 Kummer JL, Rao PK, Heidenreich KA. Apoptosis induced by 
withdrawal of trophic factors is mediated by p38 mitogen-activated protein kinase. J Biol Chem 1997; 272:20490-4.

95 Xia Z, Dickens M, Raingeaud J, Davis RJ, Greenberg ME. Opposing effects of ERK and JNK-p38 MAP kinases on apoptosis. Science 1995; 270:1326-31.

96 Juo P, Kuo CJ, Reynolds SE, et al. Fas activation of the p38 mitogen-activated protein kinase signalling pathway requires ICE/ CED-3 family proteases. Mol Cell Biol 1997; 17:24-35.

97 Henkart PA. ICE family proteases: Mediators of all apoptotic cell death? Immunity 1996; 4:195-201.

98 Fernandes-Alnemri T, Armstrong RC, Krebs J, et al. In vitro activation of CPP32 and Mch3 by Mch4, a novel human apoptotic cysteine protease containing two FADD-like domains. Proc Natl Acad Sci U S A 1996; 93:7464-9.

99 Cahill MA, Peter ME, Kischkel FC, et al. CD95 (APO-1/Fas) induces activation of SAP kinases downstream of ICE-like proteases. Oncogene 1996; 13:2087-96.

100 Huang S, Jiang Y, Li Z, et al. Apoptosis signaling pathway in T cells is composed of ICE/Ced-3 family proteases and MAP kinase kinase 6ß. Immunity 1997; 6:739-49.

101 Cardone MH, Salvesen GS, Widmann C, Johnson G, Frisch SM. The regulation of anoikis: MEKK-1 activation requires cleavage by caspases. Cell 1997; 90:315-23.

102Ziegler-Heitbrock HW, Blumenstein M, Kafferlein E, et al. In vitro desensitization to lipopolysaccharide suppresses tumour necrosis factor, interleukin- 1 and interleukin- 6 gene expression in a similar fashion. Immunology 1992; 75:264-8.

103 Takenaka K, Moriguchi T, Nishida E. Activation of the protein kinase $\mathrm{p} 38$ in the spindle assembly checkpoint and mitotic arrest. Science 1998; 280:599-602.

104Molnar A, Theodoras AM, Zon LI, Kyriakis JM. Cdc42Hs, but not Rac1, inhibits serum-stimulated cell cycle progression at G1/ S through a mechanism requiring p38/RK. J Biol Chem 1997; 272:13229-35.

105 Wang X, McGowan $\mathrm{CH}$, Zhao M, et al. Involvement of the MKK6-p38gamma cascade in gamma-radiation- induced cell cycle arrest. Mol Cell Biol 2000; 20:4543-52.

106 Wang Y, Huang S, Sah VP, et al. Cardiac muscle cell hypertrophy and apoptosis induced by distinct members of the p38 mitogenactivated protein kinase family. J Biol Chem 1998; 273:2161-8. 107 Tamura K, Sudo T, Senftleben U, et al. Requirement for p38alpha in erythropoietin expression: a role for stress kinases in erythropoiesis. Cell 2000; 102:221-31.

108 Mudgett JS, Ding J, Guh-Siesel L, et al. Essential role for p38alpha mitogen-activated protein kinase in placental angiogenesis. Proc Natl Acad Sci U S A 2000; 97:10454-9.

109Adams RH, Porras A, Alonso G, et al. Essential role of p38alpha MAP kinase in placental but not embryonic cardiovascular development. Mol. Cell 2000; 6:109-16.

110 Nagata Y, Todokoro K. Requirement of activation of JNK and p38 for environmental stress-induced erythroid differentiation and apoptosis and of inhibition of ERK for apoptosis. Blood 1999; 94:853-63.

111 Natale DR, Paliga AJ, Beier F, D'Souza SJ, Watson AJ. p38 MAPK signaling during murine preimplantation development. Dev Biol 2004; 268:76-88.

112Morooka T, Nishida E. Requirement of p38 mitogen-activated protein kinase for neuronal differentiation in PC12 cells. J Biol Chem 1998; 273:24285-8.

113 Engelman JA, Lisanti MP, Scherer PE. Specific inhibitors of p38 mitogen-activated protein kinase block 3T3- L1 adipogenesis. J Biol Chem 1998; 273:32111-20.

114Nagata Y, Takahashi N, Davis RJ, Todokoro K. Activation of p38 MAP kinase and JNK but not ERK is required for erythropoietin-induced erythroid differentiation. Blood 1998; 92:1859-69.

115 Li Y, Jiang B, Ensign WY, Vogt PK, Han J. Myogenic differentiation requires signalling through both phosphatidylinositol 3kinase and p38 MAP kinase. Cell Signal 2000; 12:751-7.

116Iwasa H., Han J, Ishikawa F. Mitogen-activated protein kinase p38 defines the common senescence-signalling pathway. Genes Cells 2003; 8:131-44.

117 Wang W, Chen JX, Liao R, et al. Sequential activation of the MEK-extracellular signal-regulated kinase and MKK3/6-p38 mitogen-activated protein kinase pathways mediates oncogenic ras-induced premature senescence. Mol Cell Biol 2002; 22:3389403.

118 Haq R, Brenton JD, Takahashi M, et al. Constitutive p38HOG mitogen-activated protein kinase activation induces permanent cell cycle arrest and senescence. Cancer Res 2002; 62:5076-82.

119Bulavin DV, Demidov ON, Saito S, et al. Amplification of PPM1D in human tumors abrogates p53 tumor-suppressor activity. Nat Genet 2002; 31:210-5. 